\title{
Biogas biodesulfurization in an anoxic biotrickling filter packed with open-pore polyurethane foam
}

\author{
Maikel Fernández, Martín Ramírez*, José Manuel Gómez, Domingo Cantero \\ Department of Chemical Engineering and Food Technologies, Faculty of Sciences, University of Cádiz, Campus de Excelencia Internacional Universitario \\ ceiA3, 11510 Puerto Real, Cádiz, Spain
}

\section{H I G H L I G H T S}

- The use of different nitrate sources did not affect the RE.

- Programmed nitrate feeding is feasible for biogas at constant $\mathrm{H}_{2} \mathrm{~S}$ IL.

- A high $\mathrm{EC}_{\mathrm{CRIT}}$ of $130 \mathrm{gS}-\mathrm{H}_{2} \mathrm{~S} \mathrm{~m}^{-3} \mathrm{~h}^{-1}$ can be achieved using OPUF.

\section{A R T I C L E I N F O}

\section{Article history:}

Received 10 May 2013

Received in revised form 6 September 2013

Accepted 21 October 2013

Available online 28 October 2013

\section{Keywords:}

Biotrickling filter

Hydrogen sulfide

Biogas

Anoxic biofiltration

Open-pore polyurethane foam

\begin{abstract}
A B S T R A C T
Biogas biodesulfurization by an anoxic biotrickling filter packed with open pore polyurethane foam at the laboratory scale (packed volume $2.4 \mathrm{~L}$ ) has been studied. The biotrickling system was operated for 620 days with biogas supplied continuously and two nitrate feeding regimes were tested (manual and programmed). Biomass immobilization was carried out under the manual nitrate feeding regime and a study was then carried out on the effects on removal efficiency of the following parameters: nitrate source, $\mathrm{H}_{2} \mathrm{~S}$ inlet load, nitrate concentration, sulfate accumulation, temperature, $\mathrm{pH}$ and trickling liquid velocity. The effect of increased $\mathrm{H}_{2} \mathrm{~S}$ inlet load was studied under the programmed nitrate feeding regime. The results show that a removal efficiency of $99 \%$ can be obtained when working under the following conditions: inlet loads below $130 \mathrm{gS} \mathrm{m}^{-3} \mathrm{~h}^{-1}$, a programmed nitrate feeding system, temperature of $30^{\circ} \mathrm{C}$, sulfate concentration below $33 \mathrm{~g} \mathrm{~L}^{-1}$, a pH between 7.3 and 7.5, and a trickling liquid velocity higher than $4.6 \mathrm{~m} \mathrm{~h}^{-1}$.
\end{abstract}

(C) 2013 Elsevier B.V. All rights reserved.

\section{Introduction}

The production and use of biogas have recently increased as this fuel represents a valuable renewable energy source. Biogas utilization produces an indirect reduction of greenhouse gas emissions through the replacement of fossil fuel [1]. However, the use of biogas is limited by the presence of hydrogen sulfide $\left(\mathrm{H}_{2} \mathrm{~S}\right)$ at high concentrations $(0.1-2 \%) . \mathrm{H}_{2} \mathrm{~S}$ is a corrosive and toxic compound that has an adverse environmental effect due to the sulfur oxides generated during combustion.

The main approaches employed for gas desulfurization are physicochemical methods. However, physicochemical methods are characterized by high consumption of energy and/or chemicals, and these methods can lead to other pollution problems such as the generation of large amounts of carbon dioxide $\left(\mathrm{CO}_{2}\right)$, nitrogen oxides or exhausted adsorbents that require disposal [2].

\footnotetext{
* Corresponding author. Tel.: +34 956016474; fax: +34 956016411.

E-mail address: martin.ramirez@uca.es (M. Ramírez).
}

One of the most widely used biological methods for the purification or treatment of gas streams is biofiltration. Biofiltration is a safer and cleaner technology. The development of biofiltration has been rapid in recent years because it is less expensive than other technologies, has good performance at the pilot scale and in industrial applications, and is feasible for the treatment of a wide variety of gaseous effluents $[3,4]$. A biotrickling filter (BTF) is a packed bed bioreactor with biomass immobilized. The gas flows through a fixed bed usually counter-currently to a mobile liquid phase. Synthetic carriers are usually used such plastic, ceramic, lava rocks, polyurethane foam, etc. First of all, the pollutant compound must be transfer from the gas to liquid phase and finally the degradation is carried out in the biofilm. Fresh medium is fed to provide nutrients and remove the oxidation products [2].

The biological removal of $\mathrm{H}_{2} \mathrm{~S}$ from biogas has been mainly studied under aerobic conditions [5-8], with very few studies carried out under anoxic conditions [9-14]. One advantage of anoxic BTFs over aerobic BTFs is that the biogas is not diluted with air and therefore the methane $\left(\mathrm{CH}_{4}\right)$ concentration is not reduced $[6,13]$. Furthermore, the electron acceptor mass transfer limitation is negligible because the nitrate solubility is very high $\left[91.2 \mathrm{~g}(100 \mathrm{~g})^{-1}\right.$ 
at $25^{\circ} \mathrm{C}$ ] [15]. Thus, for the production of pipeline grade methane anoxic biofiltration is a more feasible technology as a pretreatment for $\mathrm{H}_{2} \mathrm{~S}$ removal than the more commonly used aerobic BTFs [14].

The aim of work described here was to study the anoxic biofiltration process for $\mathrm{H}_{2} \mathrm{~S}$ removal from biogas using a BTF packed with open-pore polyurethane foam (OPUF) to increase the elimination capacity (EC) and to acquire a deeper understanding of the influence of the operating variables.

\section{Materials and methods}

\subsection{Experimental setup}

The biofiltration system used in this study was previously described by Montebello et al. [13]. Experiments were carried out during 620 days (Table 1 ) with the biogas supplied continuously $\left(68 \pm 3 \%, \mathrm{v} / \mathrm{v} \mathrm{CH} \mathrm{CH}_{4} ; 26 \pm 2 \%, \mathrm{v} / \mathrm{v} \mathrm{CO}_{2}\right)$. A BTF with a volume of $2.4 \mathrm{~L}$ (working volume bed) was packed with OPUF cubes $(26 \mathrm{~g}$, $600 \mathrm{~m}^{2} \mathrm{~m}^{-3}$, cube size $8 \mathrm{~cm}^{3}$ ) (Filter TM25450, Recticel, Spain) (Fig. 1). The volume of the liquid phase under recirculation was $2.25 \mathrm{~L}$. The biogas was produced by two Upflow Anaerobic Sludge Bed reactors (UASB) of $200 \mathrm{~L}$ (biogas flow rate up to $1 \mathrm{~L} \mathrm{~min}^{-1}$ ). In order to increase and set different $\mathrm{H}_{2} \mathrm{~S}$ concentrations, the biogas was passed through an $\mathrm{H}_{2} \mathrm{~S}$ generating column. A digital Multimeter 44 (CRISON, Spain) was used for $\mathrm{pH}$ control, which was achieved by the addition of $\mathrm{NaOH}(2 \mathrm{~N})$. Temperature was controlled using a thermostatted bath (Lauda RM6, Germany) and an Allihn refrigerant (length $300 \mathrm{~mm}$ ) (Fig. 1).

\subsection{Inoculum and medium preparation}

The inoculum was obtained from an experimental bioreactor (stirred tank reactor) installed at the 'Guadalete' Wastewater Treatment Plant (WWTP), located in Jerez de la Frontera (Cádiz), Spain. This experimental bioreactor (174 L of volume; $3 \mathrm{~h}$ of hydraulic retention time) was fed with the primary effluent [16].

Calcium nitrate [ $15 \mathrm{~g}$ of $\mathrm{Ca}\left(\mathrm{NO}_{3}\right)_{2} \cdot 4 \mathrm{H}_{2} \mathrm{O}$ ] was dissolved in the inoculum $(6 \mathrm{~L})$ and this was stored at $4{ }^{\circ} \mathrm{C}$ (inoculum solution). Three nitrate mineral media were used to test three types of nitrate source: $\mathrm{Ca}\left(\mathrm{NO}_{3}\right)_{2} \cdot 4 \mathrm{H}_{2} \mathrm{O}$ (NMCa medium), $\mathrm{NaNO}_{3}$ (NMNa medium) and $\mathrm{KNO}_{3}$ (NMK medium). The nitrate sources were diluted in modified mineral medium (M3). M3 was adapted from ATCC-1255 Thiomicrospira denitrificans medium. The M3 composition was $\left(\mathrm{g} \mathrm{L}^{-1}\right): \mathrm{KH}_{2} \mathrm{PO}_{4}, 2 ; \mathrm{NH}_{4} \mathrm{Cl}, 1 ; \mathrm{MgSO}_{4} \cdot 7 \mathrm{H}_{2} \mathrm{O}, 0.8$; iron solution, $1 \mathrm{~mL}$; trace element solution (SL-4), $2 \mathrm{~mL}$. The iron solution was prepared by dissolving $0.2 \mathrm{~g}$ of $\mathrm{FeSO}_{4} \cdot 7 \mathrm{H}_{2} \mathrm{O}$ in $100 \mathrm{~mL}$ of $\mathrm{H}_{2} \mathrm{SO}_{4}$ solution $(0.1 \mathrm{~N})$. The $\mathrm{SL}-4$ composition was $\left(\mathrm{g} \mathrm{L}^{-1}\right)$ : EDTA, 0.5 ; $\mathrm{FeSO}_{4} \cdot 7 \mathrm{H}_{2} \mathrm{O}, 0.2$; trace element solution (SL-6), $100 \mathrm{~mL}$. The SL-6 composition was ( $\mathrm{g} \mathrm{L}^{-1}$ ): $\mathrm{ZnSO}_{4} \cdot 7 \mathrm{H}_{2} \mathrm{O}, 0.1 ; \mathrm{MnCl}_{2} \cdot 4 \mathrm{H}_{2} \mathrm{O}, 0.03$; $\mathrm{H}_{3} \mathrm{BO}_{3}, 0.3 ; \mathrm{CoCl}_{2} \cdot 6 \mathrm{H}_{2} \mathrm{O}, 0.2 ; \mathrm{CuCl}_{2} \cdot 2 \mathrm{H}_{2} \mathrm{O}, 0.01 ; \mathrm{NiCl}_{2} \cdot 6 \mathrm{H}_{2} \mathrm{O}, 0.02$; $\mathrm{Na}_{2} \mathrm{MoO}_{4} \cdot 2 \mathrm{H}_{2} \mathrm{O}, 0.03$. The $\mathrm{pH}$ values of the mineral media were adjusted to 7.0 with $\mathrm{NaOH}(2 \mathrm{~N})$.

\subsection{Biomass immobilization procedure}

Biofilm formation was performed in situ in the BTF (day 1-35). The BTF was filled with $2.25 \mathrm{~L}$ of inoculum solution. Half $(50 \%, v / v)$ of the recirculation medium was replaced with inoculum solution before the nitrate was exhausted $\left(\left[\mathrm{N}-\mathrm{NO}_{3}{ }^{-}\right]<20 \mathrm{mg} \mathrm{L}^{-1}\right)$ to ensure the presence of bacteria and to improve the biofilm formation. On day 15 , after three cycles, NMCa medium $(1.125 \mathrm{~L})$ was used as a fresh medium in the immobilization procedure (final nitrate concentration in the recirculation medium of $\left.0.38 \mathrm{~g} \mathrm{~N}-\mathrm{NO}_{3}{ }^{-} \mathrm{L}^{-1}\right)$.

\subsection{Influence of the main operational variables}

The inlet load (IL), elimination capacity (EC), removal efficiency (RE) and trickling liquid velocity were described with:

$\operatorname{IL}\left(\mathrm{gS} \mathrm{m}^{-3} \mathrm{~h}^{-1}\right)=C_{0} \times \frac{Q}{V}$

$\mathrm{EC}\left(\mathrm{gS} \mathrm{m}^{-3} \mathrm{~h}^{-1}\right)=\left(C_{0}-C_{e}\right) \times \frac{Q}{V}$

$\mathrm{RE}(\%)=\frac{\left(C_{0}-C_{e}\right)}{C_{0}} \times 100$

$\operatorname{TLV}\left(\mathrm{m} \mathrm{h}^{-1}\right)=\frac{Q}{A}$

where $C_{0}$ and $C_{e}$ are the inlet and outlet concentration $\left(\mathrm{g} \mathrm{m}^{-3}\right)$ of $\mathrm{H}_{2} \mathrm{~S}$, respectively, $Q$ is the biogas volumetric flow $\left(\mathrm{m}^{3} \mathrm{~h}^{-1}\right), V$ is the packed volume $\left(\mathrm{m}^{3}\right)$ and $A$ the cross section area of the column $\left(\mathrm{m}^{2}\right)$.

The operational conditions are shown in Table 1. Two nitrate feeding regime methods were performed: manual (day 1-413) and programmed (day 414-620). In the manual method, before the nitrate was exhausted $\left(\left[\mathrm{NaNO}_{3}{ }^{-}\right]<20 \mathrm{mg} \mathrm{N}-\mathrm{NO}_{3}{ }^{-} \mathrm{L}^{-1}\right), 50 \%(\mathrm{v} / \mathrm{v})$ of the recirculation medium was replaced by fresh medium (NMCa, NMNa or NMK mediums). In the programmed method, NMNa medium was fed in by a peristaltic pump. The running time of the peristaltic pump was controlled by a logic module (Logo! 12/24RC, Siemens, Spain). The time was switched on for $1 \mathrm{~s}$ and the off time was fixed manually between 10 and $30 \mathrm{~s}$ for an IL up to $60 \mathrm{gS} \mathrm{m}^{-3} \mathrm{~h}^{-1}$ (NMNa medium concentration of $5 \mathrm{~g} \mathrm{~L}^{-1}$ of $\mathrm{NaNO}_{3}$ ) and between 20 and $50 \mathrm{~s}$ for IL higher than $60 \mathrm{gS} \mathrm{m}^{-3} \mathrm{~h}^{-1}$ (NMNa medium concentration of $10 \mathrm{~g} \mathrm{~L}^{-1}$ of $\mathrm{NaNO}_{3}$ ). The biomass immobilization was carried out under the manual nitrate feeding regime and the effects of the following variables on the $\mathrm{H}_{2} \mathrm{~S}$ RE were studied: nitrate source, $\mathrm{H}_{2} \mathrm{~S}$ IL, nitrate concentration, sulfate accumulation, temperature, $\mathrm{pH}$ and TLV. The effect of increased IL was studied under the programmed nitrate feeding regime (Table 1 ).

\subsection{Analytical methods}

The quantity of immobilized biomass was measured according to the counting method described by Gómez et al. [17]. The concentrations of sulfate, nitrate and nitrite were determined in the liquid medium by spectrophotometric methods [18]. The sulfide concentration was determined using the 1-88 NANOCOLOR ${ }^{\circledR}$ kit (Macharey-Nagel, Germany).

A specific digital sensor (GasBadge ${ }^{\circledR}$ Pro, Industrial Scientific, UK) was used to measure the $\mathrm{H}_{2} \mathrm{~S}$ concentration from 0 to $500 \mathrm{ppmv}$ (accuracy $0.1 \mathrm{ppmv}$ ). A GA2000Plus gas analyzer (Fonotest Instruments S.L., Spain) equipped with an external electrochemical $\mathrm{H}_{2} \mathrm{~S}$ gas sensor was used to measure the following: $\mathrm{H}_{2} \mathrm{~S}$ concentration from 500 to 5000 ppmv (accuracy $10 \%$ ) and $\mathrm{CH}_{4}$ and $\mathrm{CO}_{2}$ concentration by infrared absorption (accuracy $0.5 \%$ ). $\mathrm{H}_{2} \mathrm{~S}$ concentrations greater than 5000 ppmv were measured by a gas chromatograph with TCD (450-GC, Bruker, Spain).

A Quanta FIE 200 electron microscope (Philips) coupled to qualitative Energy Disperse X-ray analyzer (EDX) was used to obtain a scanning electron microscopy image (SEM) and elemental analysis of the biofilm was performed at the end of the experiment (day 619). The samples were fixed with glutaraldehyde and dehydrated by immersion in increasing concentrations of acetone solution (50-100\%). The samples were dried with $\mathrm{CO}_{2}$ to a critical point to remove the acetone and were metallized with gold (at $15 \mathrm{~mA}, 120 \mathrm{~s}$, and a distance of $35 \mathrm{~mm}$ ). 
Table 1

Variables studied and operational conditions.

\begin{tabular}{|c|c|c|c|c|c|c|c|c|}
\hline Nitrate feeding regime & Variable studied & $t(\mathrm{~d})$ & $\mathrm{pH}$ & $T^{\mathrm{a}}\left({ }^{\circ} \mathrm{C}\right)$ & $\operatorname{TLV}\left(\mathrm{m} \mathrm{h}^{-1}\right)$ & $\operatorname{IL}\left(\mathrm{gS} \mathrm{m}^{-3} \mathrm{~h}^{-1}\right)$ & $\mathrm{SO}_{4}^{2-}\left(\mathrm{g} \mathrm{L}^{-1}\right)$ & EBTR (min) \\
\hline \multirow[t]{8}{*}{ Manual } & Immobilization & $1-35$ & $6.8-7.0$ & 30 & 7 & $6-38$ & $0.2-10$ & $4.3 \pm 1.5$ \\
\hline & $\mathrm{Ca}\left(\mathrm{NO}_{3}\right)_{2} 4 \mathrm{H}_{2} \mathrm{O}$ & $35-43$ & $6.8-7.0$ & 30 & 7 & $11-35$ & $6-12$ & $2.4 \pm 0.2$ \\
\hline & $\mathrm{KNO}_{3}$ & $44-60$ & $6.8-7.0$ & 30 & 7 & $8-74$ & $5-14$ & $2.9 \pm 0.1$ \\
\hline & $\mathrm{NaNO}_{3}$ & $61-96$ & $6.8-7.0$ & 30 & 7 & $22-100$ & $10-33$ & $3.7 \pm 0.4$ \\
\hline & $\mathrm{IL} / \mathrm{SO}_{4}{ }^{2-}$ & $1-131$ & $6.8-7.0$ & 30 & 7 & $6-186$ & $0.2-40$ & $3.7 \pm 1.1$ \\
\hline & $\mathrm{T}^{a}$ & $332-350$ & $6.8-7.0$ & $15-36$ & 7 & $54 \pm 3.5$ & $17 \pm 4$ & $4.3 \pm 0.8$ \\
\hline & $\mathrm{pH}$ & $351-383$ & $6.1-7.5$ & 30 & 7 & $54 \pm 3.9$ & $1.5-18$ & $4.0 \pm 0.7$ \\
\hline & TLV & $384-398$ & $7.3-7.5$ & 30 & $2.3-21$ & $93-201$ & $2.4 \pm 0.3$ & $2.4 \pm 0.2$ \\
\hline Programmed & IL & $414-620$ & $7.3-7.5$ & 30 & $7-9$ & 11-201 & $0.3-9.8$ & $2.4-6.0$ \\
\hline
\end{tabular}

The biofilter remained in optimal conditions with loads less than $60 \mathrm{gS} \mathrm{m}^{-3} \mathrm{~h}^{-1}$ on the days not shown.

\section{Results and discussion}

\subsection{Study under the manual nitrate feeding regime}

\subsubsection{Biomass immobilization}

The first 35 days of operation were considered to be the stage for the development and adaptation of the biofilm. The biomass concentration obtained was $2.79 \times 10^{10} \pm 0.28$ cells (g dry carrier) ${ }^{-1}$. The image obtained by SEM (Fig. 2a) shows a predominance of rod-shaped bacteria in the biofilm. The accumulation of elemental sulfur in the carrier was confirmed by a qualitative EDX analysis (Fig. 2b), where it was found that elemental sulfur was the main component in the sample. Elemental sulfur has been used under anoxic conditions as an electron donor and as a carrier to grow denitrifying culture [19]. Thus, the elemental sulfur formation on the carrier, obtained by incomplete oxidation of $\mathrm{H}_{2} \mathrm{~S}$, can be considered as an interesting strategy for the immobilization of biomass during biofilter start-up.

OPUF has been used for the removal of $\mathrm{H}_{2} \mathrm{~S}$ from air [20] and for the removal of VOCs [21]. OPUF has also been employed in aerobic BTFs for $\mathrm{H}_{2} \mathrm{~S}$ removal at high concentrations (10 $000 \mathrm{ppmv}$ ) from synthetic biogas [22]. Fernández et al. [14] worked with an anoxic BTF inoculated with biomass immobilized in OPUF units from the BTF of this study and it was reached a similar biomass concentration of $1.23 \times 10^{10} \pm 0.21$ cells ( $\mathrm{g}$ dry carrier) ${ }^{-1}$ using polypropylene pall rings as packing material.

\subsubsection{Effect of different nitrate sources}

The bioreactor containing the inoculum was fed with Nutriox ${ }^{\mathrm{TM}}$ (solution of calcium nitrate concentrate) [16]. Therefore, in the immobilization stage, the BTF was fed with calcium nitrate as the nitrate source (NMCa medium). The addition of calcium nitrate might produce an accumulation of precipitate in the support due to the low solubility of calcium salts that can be formed by reaction with other components present in the recirculation medium, e.g., $\mathrm{CaCO}_{3}$ and $\mathrm{Ca}_{3}\left(\mathrm{PO}_{4}\right)_{2}$ from $\mathrm{CO}_{3}{ }^{2-}$ and $\mathrm{PO}_{4}{ }^{3-}$, respectively. Precipitate accumulation could cause clogging problems after long operating times. To avoid this problem, we tested other nitrate sources, specifically $\mathrm{KNO}_{3}$ (NMK medium, day 44-60) and $\mathrm{NaNO}_{3}$ (NMNa medium, day 61-96). The use of different nitrate sources did not affect the RE (Fig. 3a). In all cases, the RE achieved was between 98.0 and $99.9 \%$ while nitrate was not exhausted. When the nitrate concentration decreased to values below $20 \mathrm{mg} \mathrm{N}-\mathrm{NO}_{3}{ }^{-} \mathrm{L}^{-1}$ the RE dropped (Fig. 3a). The lowest RE values, in the first 70 days, were $63 \%$ (day 4 ) and $83 \%$ (days 34 and 66). However, the system showed a rapid RE recovery when nitrate was added to the recirculation medium. Soreanu et al. [10] found that the minimum required nitrate concentration to maintain the maximum $\mathrm{RE}(99 \%)$, with an IL of $4.9 \mathrm{gS} \mathrm{m}^{-3} \mathrm{~h}^{-1}$, was $20 \mathrm{mg} \mathrm{N}-\mathrm{NO}_{3}{ }^{-} \mathrm{L}^{-1}$. Fernández et al. [14] also found that the lower limit value for nitrate concentration was $20 \mathrm{mg} \mathrm{N}-\mathrm{NO}_{3}{ }^{-} \mathrm{L}^{-1}$ before replacing the medium under a manual dosage supply method.

Although the different nitrate sources did not affect the $\mathrm{H}_{2} \mathrm{~S} R E$, the use of $\mathrm{NaNO}_{3}$ is recommended because $\mathrm{NaNO}_{3}$ does not suffer from the drawbacks associated with $\mathrm{Ca}\left(\mathrm{NO}_{3}\right)_{2}$ and provides a greater mass of nitrogen per gram of compound compared to $\mathrm{KNO}_{3}$. $\mathrm{NaNO}_{3}$ also has a lower cost than $\mathrm{KNO}_{3}$.

In the first 104 days, the nitrite concentration in the recirculation medium was less than $300 \mathrm{mg} \mathrm{N}-\mathrm{NO}_{2}{ }^{-} \mathrm{L}^{-1}$ and from day 106 to 108 it was in the range $797-453 \mathrm{mg} \mathrm{N}-\mathrm{NO}_{2}{ }^{-} \mathrm{L}^{-1}$ without showing an inhibitory effect on the process. Nitrate is reduced faster than nitrite and nitrite therefore accumulates as an intermediate in the reduction to elemental nitrogen. This phenomenon is very common in denitrification processes and it has been recognized

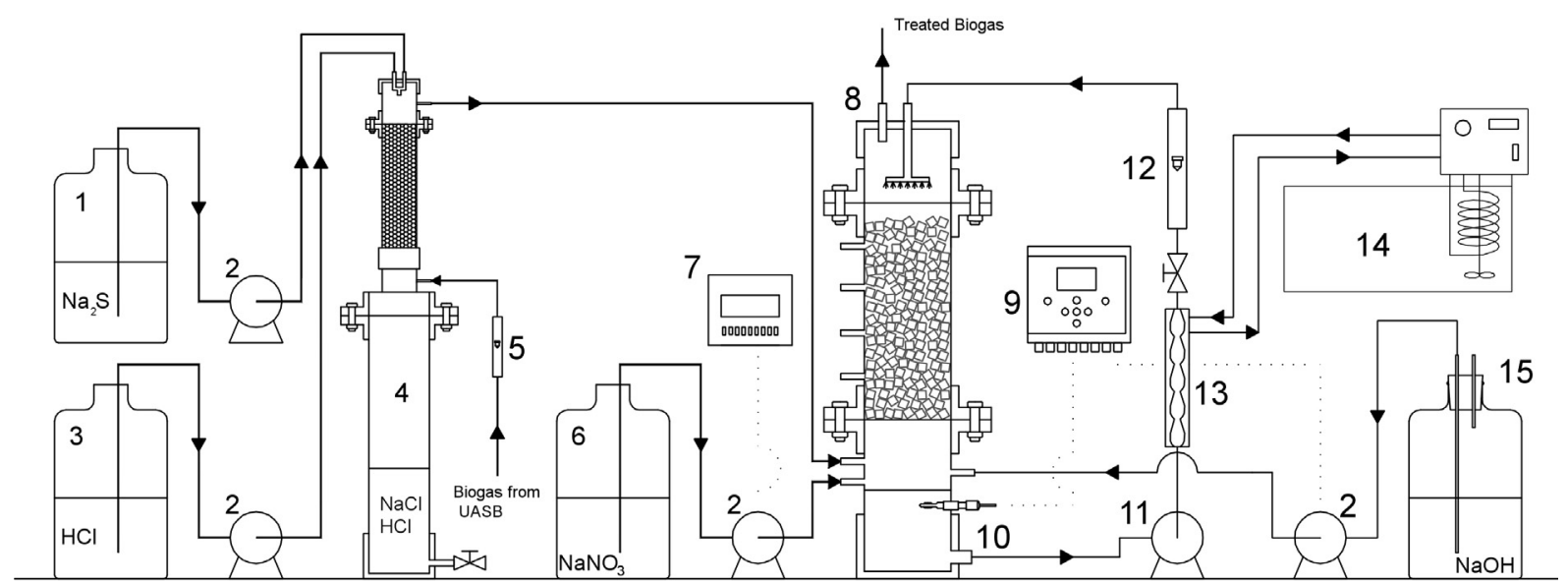

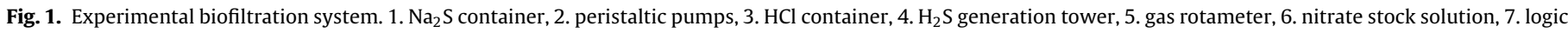
module, 8. biotrickling filter, 9. pH controller, 10. pH electrode, 11. centrifugal pump, 12. liquid rotamter, 13. Ahllin refrigerant, 14. thermostatic bath, 15. NaOH container. 


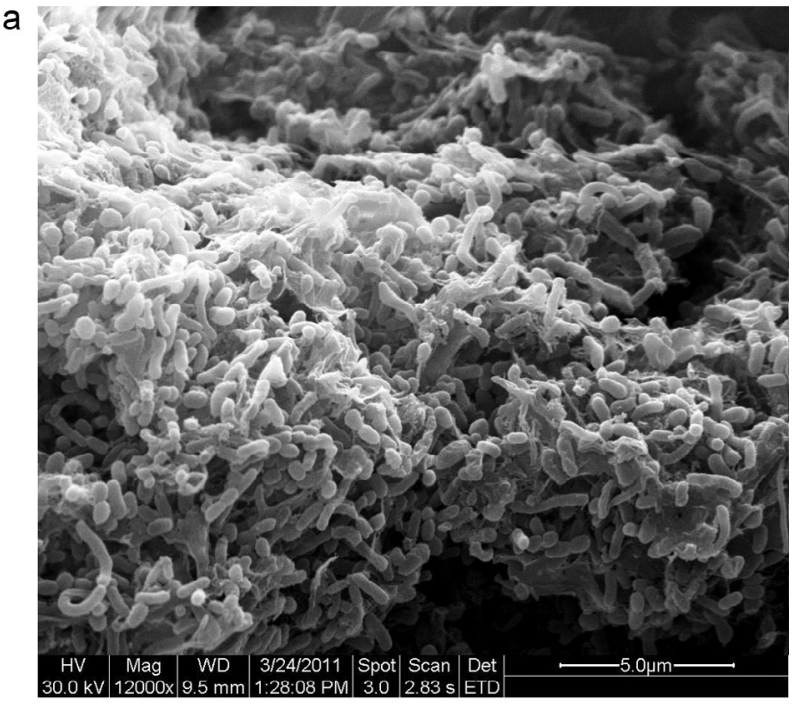

b

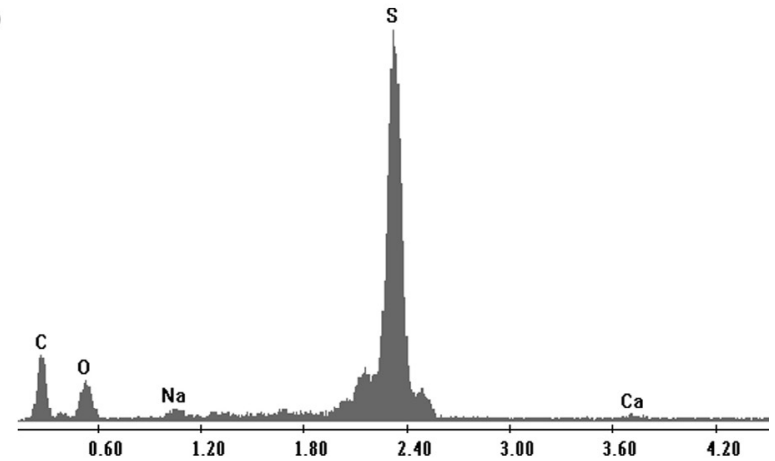

Fig. 2. (a) Scanning electron microscopy image. (b) EDX analysis.

as one of the causes of inhibition. Krishnakumar and Manilal [23] observed that above $100 \mathrm{mg} \mathrm{N}-\mathrm{NO}_{2}{ }^{-} \mathrm{L}^{-1}$, the sulfide oxidation rate declined and at $500 \mathrm{mg} \mathrm{N}-\mathrm{NO}_{2}{ }^{-} \mathrm{L}^{-1}$ it was completely arrested. However, Soreanu et al. $[9,10]$ worked with nitrite concentrations up to $300 \mathrm{mg} \mathrm{N}-\mathrm{NO}_{2}{ }^{-} \mathrm{L}^{-1}$ without observing inhibition of an anoxic biofiltration process. Similar behavior was found in this study. The lack of inhibition by nitrite is a great advantage because nitrite

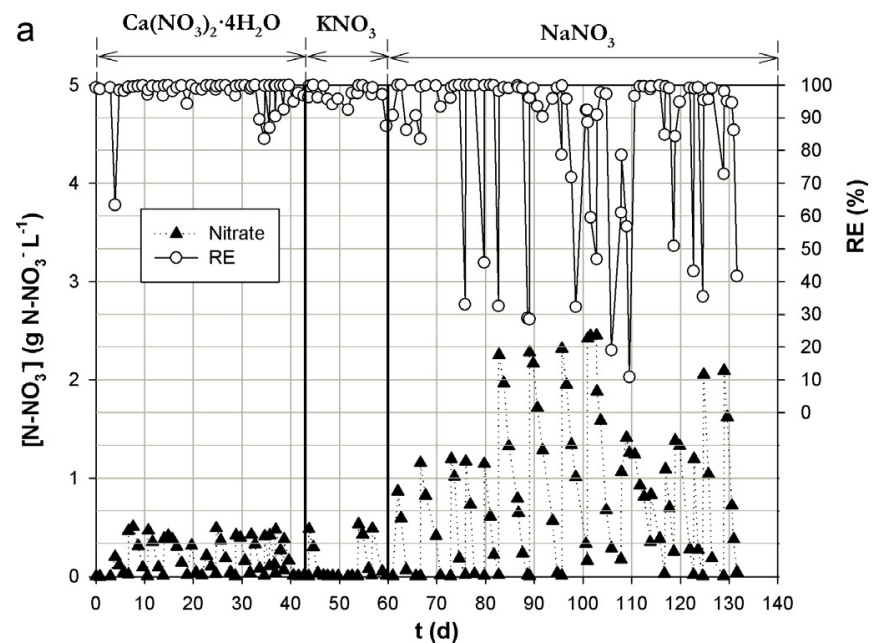

could be used instead of nitrate as an electron acceptor source. Nitrite production from ammonia requires a lower oxygen supply and thus lower energy consumption [24], although further study is required to confirm this behavior.

The establishment of high RE values from the first moments after the inoculation is an advantage for any eventual industrial application because the biological activity in the biofilter starts up immediately after inoculation. Nevertheless the IL must be increased slowly (Fig. 3b). It was concluded that the nitrate-reducing and sulfide-oxidizing bacteria (NR-SOB) were immobilized on the carrier very quickly because the RE remained constant after replacement of the recirculation medium. The biomass population was characterized by PCR-DGGE and the banding patterns showed several bands (data not published). So, it is very likely the existence of several NR-SOB species.

\subsubsection{Effect of IL}

The mean nitrate reduction rates were $0.154 \pm 0.044$ (day $6-62$ ), $0.329 \pm 0.091$ (day 62-82), $0.401 \pm 0.004$ (day 82-108) and

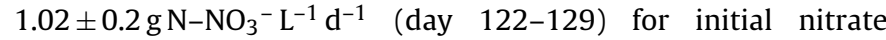
concentrations of $0.43 \pm 0.08, \quad 1.11 \pm 0.14, \quad 2.31 \pm 0.07$ and $1.7 \pm 0.5 \mathrm{~g} \mathrm{~N}^{-\mathrm{NO}_{3}}{ }^{-} \mathrm{L}^{-1}$, respectively. Treatment of high nitrate concentrations in wastewater has led to high denitrification rates: $5.64 \mathrm{~g} \mathrm{~N}-\mathrm{NO}_{3}{ }^{-} \mathrm{L}^{-1} \mathrm{~d}^{-1}$ for complete denitrification using thiosulfate

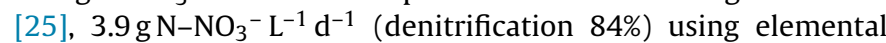

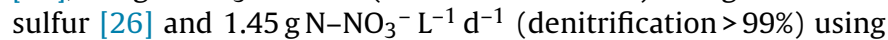
sulfide [27]. Soreanu et al. [10] used an anoxic BTF and obtained

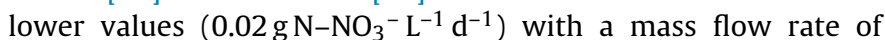
$1.5 \mathrm{~g} \mathrm{H}_{2} \mathrm{Sd}^{-1}$ (IL of $4.9 \mathrm{gS} \mathrm{m}^{-3} \mathrm{~h}^{-1}$ ). These differences could be attributed to the lower nitrate concentration and $\mathrm{H}_{2} \mathrm{~S}$ IL.

It is known that the $\mathrm{N}-\mathrm{NO}_{3}{ }^{-} / \mathrm{S}-\mathrm{H}_{2} \mathrm{~S}$ ratio affects the $\mathrm{S}-\mathrm{SO}_{4}{ }^{-2} / \mathrm{S}^{0}$ ratio obtained $[13,28]$. Nitrite was not accumulated, so partial denitrification was not considered. Complete denitrification kinetic can by describe by the following equations [10]:

$$
\begin{aligned}
& 5 \mathrm{H}_{2} \mathrm{~S}+2 \mathrm{NO}_{3}{ }^{-} \rightarrow 5 \mathrm{~S}^{0}+\mathrm{N}_{2}+4 \mathrm{H}_{2} \\
& \left.+2 \mathrm{OH}^{-} \text {(complete } \mathrm{H}_{2} \mathrm{~S} \text { oxidation }\right)
\end{aligned}
$$

$$
5 \mathrm{H}_{2} \mathrm{~S}+8 \mathrm{NO}_{3}{ }^{-} \rightarrow 5 \mathrm{SO}_{4}{ }^{-2}+4 \mathrm{~N}_{2}+4 \mathrm{H}_{2} \mathrm{O}
$$$$
+2 \mathrm{H}^{+} \text {(partial } \mathrm{H}_{2} \text { S oxidation) }
$$

b

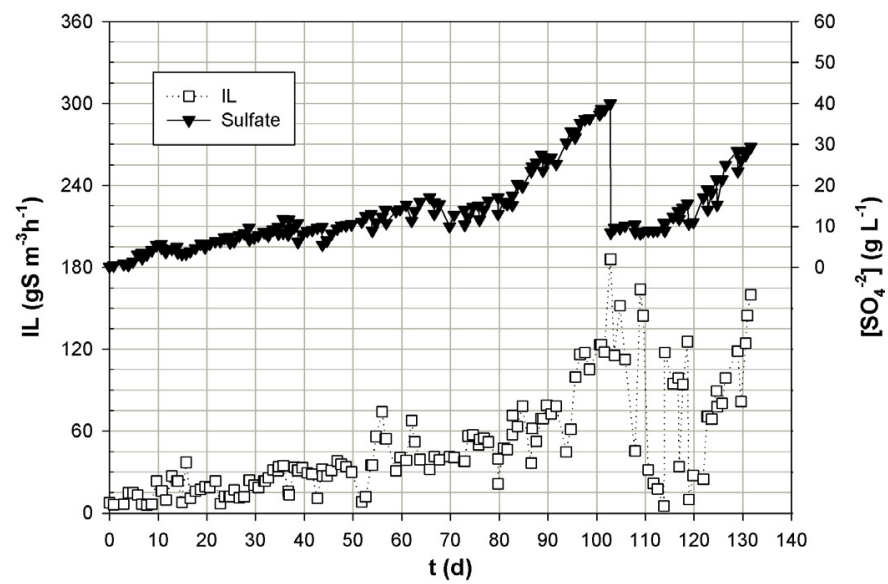

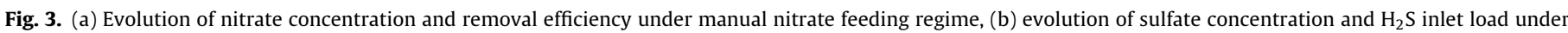
manual nitrate feeding regime. 
According Eq. (5) if the N/S ratio is $0.4 \mathrm{~mol} \mathrm{~mol}^{-1}$ the sulfide can be oxidized mainly into sulfur and sulfide can be completely oxidized into sulfate when there is excess nitrate (Eq. (6), N/S ratio of $1.6 \mathrm{~mol} \mathrm{~mol}^{-1}$ ) [10]. Under the manual nitrate feeding regime (day 1-413) the molar $\mathrm{N} / \mathrm{S}$ ratio was between 0.29 and $2.26 \mathrm{~mol} \mathrm{~mol}^{-1}$ (average $0.77 \pm 0.42 \mathrm{~mol} \mathrm{~mol}^{-1}$ ). However, in $81 \%$ of the cycles the molar $\mathrm{N} / \mathrm{S}$ ratio was below $1 \mathrm{~mol} \mathrm{~mol}^{-1}$. For each cycle (period between nitrate dosage) the nitrate concentration decreased rapidly and therefore the N/S ratio also decreased. As a result, the $\mathrm{S}-\mathrm{SO}_{4}{ }^{-2} / \mathrm{S}^{0}$ ratio produced was not constant for each cycle under this nitrate feeding regime (manual). The resulting $\mathrm{S}-\mathrm{SO}_{4}{ }^{-2} / \mathrm{S}^{0}$ ratio was calculated under the programmed nitrate feeding regime as the nitrate concentration can be kept constant and therefore the mass balance can be achieved with great accuracy.

Similar N/S ratios were reported by Manconi et al. [29], who achieved complete oxidation of sulfide to sulfate with an N/S ratio of $0.89 \mathrm{~mol} \mathrm{~mol}^{-1}$. Wang et al. [28] worked at an N/S ratio between 0.4 and $0.6 \mathrm{~mol} \mathrm{~mol}^{-1}$ for the oxidation of sulfide to elemental sulfur at a high sulfide concentration (300 $\mathrm{mg} \mathrm{L}^{-1}$ ) and Soreanu et al. [10] used an $\mathrm{N} / \mathrm{S}$ ratio of $0.78 \mathrm{~mol} \mathrm{~mol}^{-1}$.

Sulfate could have an inhibitory effect on RE and the effect of sulfate accumulation was therefore evaluated. The sulfate concentration was progressively increased from $15.2 \mathrm{~g} \mathrm{~L}^{-1}$ (day 82) to $40 \mathrm{~g} \mathrm{~L}^{-1}$ on day 103 (Fig. 3b). The critical EC was $99.8 \mathrm{gS} \mathrm{m}^{-3} \mathrm{~h}^{-1}$ (RE $>99 \%$, Empty bed residence time (EBRT) $3.4 \mathrm{~min}$ ) and this value was obtained while the sulfate concentration was less than $33 \mathrm{~g} \mathrm{~L}^{-1}$ and the nitrate was not exhausted. For sulfate concentrations higher than $33 \mathrm{~g} \mathrm{~L}^{-1}$ (day 96-103) the RE fluctuated in the range 32.3-95.8\%. This behavior could be due to the high sulfate concentration or the high IL (from 105 to $186 \mathrm{gS} \mathrm{m}^{-3} \mathrm{~h}^{-1}$ ) during this period. However, the RE increased from 46.9 to $90.9 \%$ for an IL of $186 \mathrm{gS} \mathrm{m}^{-3} \mathrm{~h}^{-1}$ (day 103), with the maximum EC $\left(169 \mathrm{gS} \mathrm{m}^{-3} \mathrm{~h}^{-1}\right.$, EBRT $\left.3.4 \mathrm{~min}\right)$ reached when the sulfate concentration decreased from 40 to $8.5 \mathrm{~g} \mathrm{~L}^{-1}$ on day 103. At low sulfate concentrations ( $<15 \mathrm{~g} \mathrm{~L}^{-1}$, from day 103 to day 118 ) a decrease in RE was observed at high IL, indicating that the BTF shows instability at high IL ( $\left.>115 \mathrm{gS} \mathrm{m}^{-3} \mathrm{~h}^{-1}\right)$, even at low sulfate concentrations. At IL values greater than $115 \mathrm{gS} \mathrm{m}^{-3} \mathrm{~h}^{-1}$ the BTF did not reach steady-state conditions and the sulfide concentration in the recirculation medium increased (the color of the recirculation medium became yellow when the sulfide concentration in the recirculation medium was higher than $45 \mathrm{mg} \mathrm{S}^{-2} \mathrm{~L}^{-1}$ ). Under non-steady state conditions the RE was constant for a period not longer than $24 \mathrm{~h}$ and, in this case, the NR-SOB activity was seriously affected by the increased sulfide concentration in the medium and the RE dropped. After overloading, the $\mathrm{H}_{2} \mathrm{~S}$ IL was reduced to $30 \mathrm{gS} \mathrm{m}^{-3} \mathrm{~h}^{-1}$ and the system was restored to normal operation within $24 \mathrm{~h}$. Thus, under the manual regime an IL greater than $99.8 \mathrm{gS} \mathrm{m}^{-3} \mathrm{~h}^{-1}$ and sulfate concentration greater than $33 \mathrm{gL}^{-1}$ must been avoided.

\subsubsection{Effect of temperature}

It was observed that the optimum temperature for anoxic $\mathrm{H}_{2} \mathrm{~S}$ removal from biogas was $30^{\circ} \mathrm{C}$. This value is in agreement with the values reported in the literature for most denitrifying autotrophic microorganisms [30]. The temperature was fixed at $30^{\circ} \mathrm{C}$ until day 131 and an RE of $100 \%$ was reached for an IL of $57.4 \mathrm{gS} \mathrm{m}^{-3} \mathrm{~h}^{-1}$ (day 74). When the temperature was increased up to $36^{\circ} \mathrm{C}$ the RE decreased slowly and then remained constant at $88 \pm 2 \%$ at an IL of $55 \pm 2 \mathrm{gS} \mathrm{m}^{-3} \mathrm{~h}^{-1}$. However, when the temperature was decreased to below $30^{\circ} \mathrm{C}$, a linear RE decrease to values of $65 \pm 2 \%$ at $15^{\circ} \mathrm{C}$ was observed. This finding shows that the NR-SOB population was more sensitive to inhibition at temperatures below $30^{\circ} \mathrm{C}$.
Table 2

Removal efficiency versus trickling liquid velocity at several inlet load.

\begin{tabular}{clll}
\hline $\operatorname{TLV}\left(\mathrm{m} \mathrm{h}^{-1}\right)$ & \multicolumn{2}{l}{$\mathrm{IL}\left(\mathrm{gS} \mathrm{m}^{-3} \mathrm{~h}^{-1}\right)$} & 201 \\
\cline { 2 - 4 } & 93 & 157 & 78.7 \\
\hline 2.3 & 89.6 & 82.9 & 85.1 \\
4.6 & 98.0 & 93.0 & 88.8 \\
9.1 & 99.0 & 94.9 & 91.8 \\
13.7 & 99.2 & 96.0 & 92.2 \\
18.3 & 99.6 & 96.4 & 92.9 \\
20.6 & 99.8 & 96.1 & \\
\hline
\end{tabular}

\subsubsection{Effect of $\mathrm{pH}$}

A high stability of RE $(99.0 \pm 1 \%)$ was observed when the $\mathrm{pH}$ was increased up to 7.3-7.5. A slightly alkaline $\mathrm{pH}$ favored the conversion of nitrate to nitrogen without the accumulation of intermediates (Eq. (7)) [31] and an increase in the $\mathrm{H}_{2} \mathrm{~S}$ solubility was observed.

$\mathrm{NO}_{3}{ }^{-} \rightarrow \mathrm{NO}_{2}{ }^{-} \rightarrow \mathrm{NO} \rightarrow \mathrm{N}_{2} \mathrm{O} \rightarrow \mathrm{N}_{2}$

The $\mathrm{H}_{2} \mathrm{~S}$ acid dissociation constants are 7.04 and 11.95 [32], so at pH values higher than 7.04 the $\mathrm{HS}^{-}$concentration increased greatly. In this situation a slightly alkaline $\mathrm{pH}$ contributes to a higher $\mathrm{RE}$ because it improves the $\mathrm{H}_{2} \mathrm{~S}$ mass transfer from the gas phase to the liquid phase [33]. At pH values in the range 6.8-7.0 the RE values showed some instability, with RE values from 90.9 to $99.9 \%$ obtained, and when the $\mathrm{pH}$ was decreased to 6.5 the RE fell to $70 \%$. The $\mathrm{pH}$ always decreased so that acid addition was not needed. The main oxidation product was elemental sulfur at low N/S ratio. However proton production was higher than hydroxide anion production. Hence, the kinetic must be more complex, although Eqs. (5) and (6) could be a good approximation.

Thomsen et al. [31] observed that the reduction of nitrous oxide is the slowest step in the reduction of $\mathrm{NO}_{3}{ }^{-}$to $\mathrm{N}_{2}$. This stage can be affected when working at acidic $\mathrm{pH}$ due to progressive inhibition of the nitrous oxide reductase activity, which causes an accumulation of $\mathrm{N}_{2} \mathrm{O}$ that is very toxic to denitrifying bacteria. The percentages of the flux reducing equivalents to reduction of nitrate to nitrogen obtained by Thomsen et al. [31] were 38, 87, 63, 30, 26 and 6 at $\mathrm{pH}$ values of 8.5, 7.5, 7.0, 6.5, 6.0 and 5.5, respectively. An optimum working $\mathrm{pH}$ between 7.3 and 7.5 is therefore proposed. The $\mathrm{pH}$ in this study was not increased above 7.5 because the system becomes more sensitive to $\mathrm{H}_{2} \mathrm{~S}$ overload due to the increase in $\mathrm{H}_{2} \mathrm{~S}$ solubility with $\mathrm{pH}$.

\subsubsection{Effect of $T L V$}

Six TLV values were studied: 2.3, 4.6, 9.1, 13.7, 18.3 and $20.6 \mathrm{~m} \mathrm{~h}^{-1}$ at IL of 93,157 and $201 \mathrm{gS} \mathrm{m}^{-3} \mathrm{~h}^{-1}$. The gas velocity was $4.18 \pm 0.7 \mathrm{~m} \mathrm{~h}^{-1}$ and therefore the liquid/gas velocity ratios were in the range 0.54-4.9. The RE was constant for TLV values higher than $13.7 \mathrm{~m} \mathrm{~h}^{-1}$ for the three IL tested (Table 2). RE decreased slightly for a TLV of 18.3 up to $4.6 \mathrm{~m} \mathrm{~h}^{-1}$ at IL values below $157 \mathrm{gS} \mathrm{m}^{-3} \mathrm{~h}^{-1}$ from 99.6 to $98.0 \%$ and from 96.4 to $93.0 \%$ for 93 and $157 \mathrm{gS} \mathrm{m}^{-3} \mathrm{~h}^{-1}$, respectively. This reduction was more marked for an IL of $201 \mathrm{gS} \mathrm{m}^{-3} \mathrm{~h}^{-1}$, with the RE decreasing from 92.2 to $85.1 \%$. In all cases the RE fell quickly on decreasing TLV from 4.6 to $2.3 \mathrm{~m} \mathrm{~h}^{-1}$; 98.0 to $89.6 \%, 93.0$ to $82.9 \%$ and 85.1 to $78.7 \%$ for IL values of 93,157 and $201 \mathrm{gS} \mathrm{m}^{-3} \mathrm{~h}^{-1}$, respectively. It is clear that TLV has a significant effect on the $\mathrm{H}_{2} \mathrm{~S}$ mass transfer between the gas and liquid phases and this therefore influences RE. It is recommended to work with a TLV higher than $4.6 \mathrm{~m} \mathrm{~h}^{-1}$ to prevent RE reduction, with a maximum value of $15.0 \mathrm{~m} \mathrm{~h}^{-1}$. The effect of TLV has been studied with polypropylene pall rings as a carrier under anoxic conditions, with an optimal TLV of $15 \mathrm{~m} \mathrm{~h}^{-1}$ [14]. The use of OPUF therefore allows a better mass transfer due its higher specific surface area. 


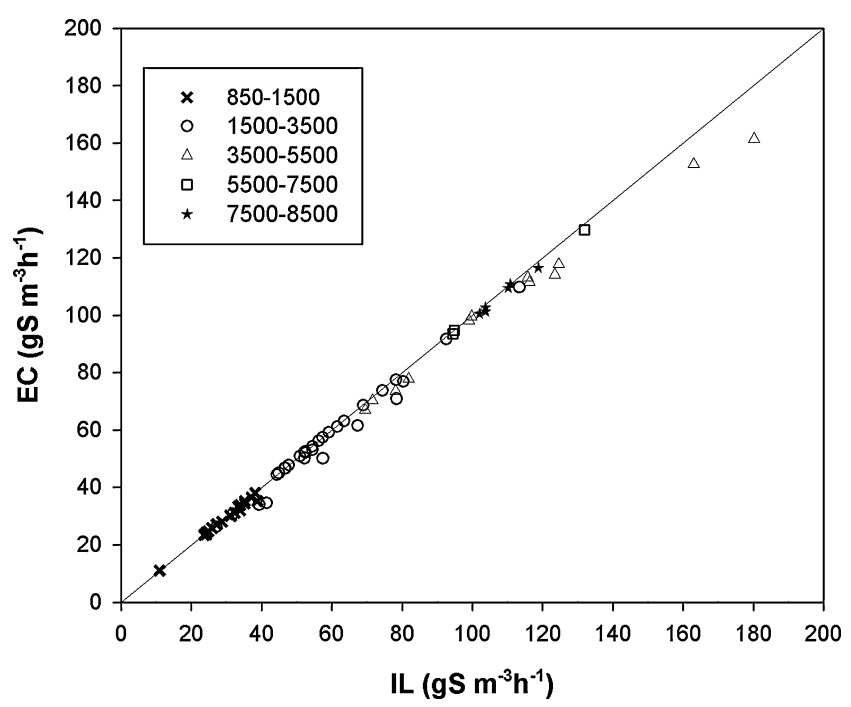

Fig. 4. Elimination capacity versus inlet load under programmed nitrate feeding regime. Icons show the range of inlet $\mathrm{H}_{2} \mathrm{~S}$ concentration (ppmv).

Gabriel and Deshusses [20] employed OPUF in an aerobic BTF for the removal of $\mathrm{H}_{2} \mathrm{~S}$ from air with a TLV of $1.7 \mathrm{~m} \mathrm{~h}^{-1}$ and $\mathrm{RE}$ values of $97 \%$ were achieved for IL between 14.1 and $89.4 \mathrm{gS} \mathrm{m}^{-3} \mathrm{~h}^{-1}$ and with low inlet concentrations of $\mathrm{H}_{2} \mathrm{~S}$ ( $\left.<30 \mathrm{ppmv}\right)$. Fortuny et al. $[8,22]$ used aerobic BTFs with OPUF and polypropylene grids [HD Q$\left.\operatorname{PAC}^{\circledR}\left(0.16 \times 0.16^{\prime \prime}\right)\right]$ to remove $\mathrm{H}_{2} \mathrm{~S}$ from synthetic biogas, working with TLVs between 1 and $5 \mathrm{~m} \mathrm{~h}^{-1}$ for OPUF and 2.4 and $3.8 \mathrm{~m} \mathrm{~h}^{-1}$ for HD Q-PAC ${ }^{\circledR}$. Both studies involved high $\mathrm{H}_{2} \mathrm{~S}$ IL and values of $370 \mathrm{gS} \mathrm{m}^{-3} \mathrm{~h}^{-1}$ and a maximum EC of $270 \mathrm{gS} \mathrm{m}^{-3} \mathrm{~h}^{-1}$ were achieved.

\subsection{Study of programmed nitrate feeding regime}

\subsubsection{Effect of IL}

The critical EC was $130 \mathrm{gS} \mathrm{m}^{-3} \mathrm{~h}^{-1}$ (RE 99\%, EBRT $2.4 \mathrm{~min}$ ) (Fig. 4) and this is higher than the critical EC obtained under the manual feeding regime (99.8 $\mathrm{gS} \mathrm{m}^{-3} \mathrm{~h}^{-1}, \mathrm{RE}<99 \%$, EBRT $\left.3.4 \mathrm{~min}\right)$. However, the maximum EC had the same value $\left(170 \mathrm{gS} \mathrm{m}^{-3} \mathrm{~h}^{-1}\right.$, EBRT $2.4 \mathrm{~min}$ ) under both nitrate feeding regimes. Similar results were also obtained on using polypropylene Pall rings, with a critical EC of $120 \mathrm{gS} \mathrm{m}^{-3} \mathrm{~h}^{-1}$ (RE 99\%, EBRT $2.4 \mathrm{~min}$ ) and a maximum EC of $171 \mathrm{gS} \mathrm{m}^{-3} \mathrm{~h}^{-1}$ (RE 85\%, EBRT $2.4 \mathrm{~min}$ ) [14].

At constant $\mathrm{H}_{2} \mathrm{~S}$ IL the programmed nitrate feeding regime can achieve steady-state conditions characterized by constant RE without nitrate exhaustion, nitrite accumulation (less than $80 \mathrm{mg} \mathrm{L}^{-1}$ ) and sulfate accumulation (less than $10 \mathrm{~g} \mathrm{~L}^{-1}$ ).

The N/S ratio can be easily calculated under the programmed nitrate feeding regime due to the stability of nitrate and product concentrations. A sulfur mass balance was performed by subtraction [34]. Sulfur mass balances showed a linear increase in sulfur production versus the ratio of supplied nitrate $\left(\mathrm{mol} \mathrm{N}-\mathrm{NO}_{3}{ }^{-}\right)$and sulfide removed ( $\mathrm{mol} \mathrm{S}-\mathrm{H}_{2} \mathrm{~S}$ ) (Fig. 5).

Therefore, on working at a high IL ( $\left.>164 \mathrm{gS} \mathrm{m}^{-3} \mathrm{~h}^{-1}\right)$ elemental sulfur was the main product (70\%) because the system was under nitrate-limited conditions. Similar results were obtained by Soreanu et al. [9] and Fortuny et al. [22], who observed that 65\% of the $\mathrm{H}_{2} \mathrm{~S}$ degraded was oxidized to elemental sulfur. Fernández et al. [14] also obtained a similar level of elemental sulfur production (68\%) on working under nitrate-limiting conditions ( $\mathrm{N} / \mathrm{S}$ ratio of $0.7 \pm 0.32 \mathrm{~mol} \mathrm{~mol}^{-1}$ ).

Comparison of these results with those reported in studies on the anoxic removal of $\mathrm{H}_{2} \mathrm{~S}$ in biogas through denitrification processes shows that the critical EC values achieved in this study are higher than those obtained by Soreanu et al. [10,11], who reported

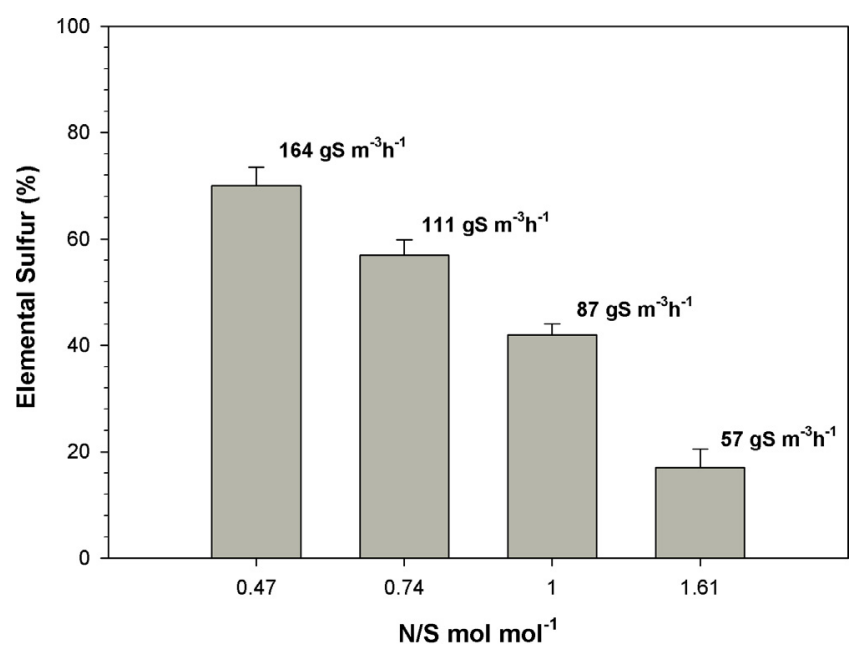

Fig. 5. Sulfur mass balance.

values between 9.0 and $11.8 \mathrm{gS} \mathrm{m}^{-3} \mathrm{~h}^{-1}$ on using anoxic BTFs packed with plastic fibers and volcanic rock (RE between 95 and 99\% with EBRTs between 10.3 and $16.0 \mathrm{~min}$ ). Another study on anoxic biofiltration by Soreanu et al. [35] gave a maximum EC value of $50 \mathrm{gS} \mathrm{m}^{-3} \mathrm{~h}^{-1}$ with an EBRT of $6 \mathrm{~min}$. The higher EC values obtained in this study may be due to the use of OPUF as a carrier and the prior stimulation of inoculum by nitrate addition - a combination of factors that was able to improve RE.

Fortuny et al. [8] carried out a study on $\mathrm{H}_{2} \mathrm{~S}$ removal from biogas using an aerobic BTF and they found a lower critical EC of $79 \mathrm{gS} \mathrm{m}^{-3} \mathrm{~h}^{-1}$ and a maximum EC of $144 \mathrm{gS} \mathrm{m}^{-3} \mathrm{~h}^{-1}$ on using HD Q-PAC ${ }^{\circledR}$ as a carrier and an EBRT lower than that employed in the present study. However, in another study by the same authors [22], using $\mathrm{HD}$ Q-PAC ${ }^{\circledR}$ and OPUF, maximum EC values greater than those found in this study ( 250 and $280 \mathrm{gS} \mathrm{m}^{-3} \mathrm{~h}^{-1}$ ) were obtained with EBRTs of 2.8 and $3 \mathrm{~min}$. In a previous study on the simultaneous removal of methylmercaptan and $\mathrm{H}_{2} \mathrm{~S}$ from biogas on the biofilter used in this work, EC values similar to those in this experiment were obtained, i.e. critical EC of $84.7 \mathrm{gS} \mathrm{m}^{-3} \mathrm{~h}^{-1}$ (RE 98\%) and maximum EC of $142 \mathrm{gS} \mathrm{m}^{-3} \mathrm{~h}^{-1}$ (RE 47\%) [13]. It can be concluded that the anoxic BTF used in this study is capable of degrading high $\mathrm{H}_{2} \mathrm{~S}$ IL to a similar extent as those achieved with aerobic BTFs used for removal of this compound from biogas.

Programmed nitrate feeding is feasible for biogas treatment without a change in the $\mathrm{H}_{2} \mathrm{~S}$ IL because the nitrate supply system cannot detect the change in $\mathrm{H}_{2} \mathrm{~S}$ IL. Therefore, on increasing the $\mathrm{H}_{2} \mathrm{~S}$ IL, nitrate is exhausted and RE decreases; however, on decreasing the $\mathrm{H}_{2} \mathrm{~S}$ IL, nitrate was accumulated in the medium. This problem could be solved by applying a feed forward control for the measurement of the $\mathrm{H}_{2} \mathrm{~S}$ inlet concentration and biogas flow rate, or by measuring the nitrate with an ion-selective electrode (ISE). However, commercial ISE suffer from interference or inhibition by nitrite, sulfate and/or sulfide. Recently, Fernández et al. [14] developed another simple method for nitrate addition in an anoxic BTF. These authors employed an oxide reduction potential (ORP) measurement in the recirculation medium in order to detect $\mathrm{H}_{2} \mathrm{~S}$ accumulation and therefore avoid nitrate depletion. However, it was impossible to ascertain whether $\mathrm{H}_{2} \mathrm{~S}$ accumulation was due to nitrate depletion or to $\mathrm{H}_{2} \mathrm{~S}$ overload.

The cost per cubic meter of biogas treated by aerobic BTF, $\mathrm{FeCl}_{3}$ addition and chemical-oxidative scrubbing are $0.013,0.024$ and $0.30 € \mathrm{~m}^{-3}$ of biogas respectively [36,37]. For anoxic BTF the investment cost compared to aerobic BTF is very similar. However, there is an additional operative cost related with nitrate consumption. In order to remove $1 \mathrm{~kg}$ of $\mathrm{H}_{2} \mathrm{~S}$ it is necessary $1.85 \mathrm{~kg}$ of $\mathrm{NaNO}_{3}$ (at 
$\mathrm{N} / \mathrm{S}$ ratio of $0.74 \mathrm{~mol} \mathrm{~mol}^{-1}$ ). Considering the previously study published by Tòmas et al. the cost will be of $0.016 € \mathrm{~m}^{-3}$ of biogas at $\mathrm{NaNO}_{3}$ price of $0.45 € \mathrm{~kg}^{-1}$ (price buying $1 \mathrm{Tm}, 2009$ ). Hence, anoxic BTF could be considering a promising technology.

\section{Conclusion}

Our experimental results confirmed that the use of different nitrate sources did not affect the RE, although $\mathrm{NaNO}_{3}$ is recommended. The maximum EC of $170 \mathrm{gS} \mathrm{m}^{-3} \mathrm{~h}^{-1}$ (EBRT $2.4 \mathrm{~min}$ ) under both regimes. The optimal conditions were: temperature of $30^{\circ} \mathrm{C}$, sulfate concentration below $33 \mathrm{~g} \mathrm{~L}, \mathrm{pH}$ between 7.3 and 7.5 and TLV higher than $4.6 \mathrm{~m} \mathrm{~h}^{-1}$. In regard to nitrite concentration, high concentrations were reached without showing an inhibitory effect on the process, so nitrite could be used instead nitrate as an electron acceptor source. To sum up, OPUF has great properties as carrier for anoxic biofiltration and it can be reached critical EC of $130 \mathrm{gS} \mathrm{m}^{-3} \mathrm{~h}^{-1}$ (RE 99\%, EBRT $2.4 \mathrm{~min}$ ) under programmed nitrate feeding regime.

\section{Acknowledgements}

The authors wish to express their sincere gratitude to the Spanish Ministry of Science and Innovation and the European FEDER funds for providing financial support through the projects CTM2009-14338-C03-02 and UNCA08-1E-003. The authors also thank the Iberoamerican Ph.D. Program in Sciences of the University of Cádiz and the Heineken ${ }^{\circledR}$ brewery located in Jaén (Spain) for providing the granular sludge for the biogas production.

\section{References}

[1] P. Weiland, Biogas production: current state and perspectives, Appl. Microbiol. Biotechnol. 85 (2010) 849-860.

[2] M. Ramírez, F. Almenglo, M. Fernández, J.M. Gómez, D. Cantero, Biodesulphurisation of $\mathrm{H}_{2} \mathrm{~S}$ - bearing industrial gas streams, in: L. Gonzaga, D. Monteiro, C.E. Gomes (Eds.), Biohydrometallurgical Processes: A practical approach, CETEM/MCTI, Rio de Janerio, 2011, pp. 271-290.

[3] G. Li, Z. Zhang, H. Sun, J. Chen, T. An, B. Li, Pollution profiles, health risk of VOCs and biohazards emitted from municipal solid waste transfer station and elimination by an integrated biological-photocatalytic flow system: a pilotscale investigation, J. Hazard. Mater. 250-251 (2013) 147-154.

[4] R. Jiang, S. Huang, A.T. Chow, J. Yang, Nitric oxide removal from flue gas with a biotrickling filter using Pseudomonas putida, J. Hazard. Mater. 164 (2009) 432-441.

[5] D. Ramírez-Sáenz, P.B. Zarate-Segura, C. Guerrero-Barajas, E.I. García-Peña, $\mathrm{H}_{2} \mathrm{~S}$ and volatile fatty acids elimination by biofiltration: clean-up process for biogas potential use, J. Hazard. Mater. 163 (2009) 1272-1281.

[6] S. Chaiprapat, R. Mardthing, D. Kantachote, S. Karnchanawong, Removal of hydrogen sulfide by complete aerobic oxidation in acidic biofiltration, Process Biochem. 46 (2011) 344-352.

[7] M. Fortuny, M. Deshusses, X. Gamisans, C. Casas, D. Gabriel, F.J. Lafuente, High $\mathrm{H}_{2} \mathrm{~S}$ concentration abatement in a biotrickling filter: start-up at controlled $\mathrm{pH}$ and effect of the EBRT and $\mathrm{O}_{2} / \mathrm{H}_{2} \mathrm{~S}$ supply ratio, in: C. Kennes, M. Veiga (Eds.), Proceeding of the II International Congress on Biotechniques for Air Pollution Control, Universidade da Coruña, A Coruña, 2007, pp. 251-262.

[8] M. Fortuny, X. Gamisans, M.A. Deshusses, J. Lafuente, C. Casas, D. Gabriel, Operational aspects of the desulfurization process of energy gases mimics in biotrickling filters, Water Res. 45 (2011) 5665-5674.

[9] G. Soreanu, M. Béland, P. Falletta, K. Edmonson, P. Seto, Laboratory pilot scale study for $\mathrm{H}_{2} \mathrm{~S}$ removal from biogas in an anoxic biotrickling filter, Water Sci. Technol. 57 (2008) 201-207.

[10] G. Soreanu, M. Béland, P. Falletta, K. Edmonson, P. Seto, Investigation on the use of nitrified wastewater for the steady-state operation of a biotrickling filter for the removal of hydrogen sulphide in biogas, J. Environ. Eng. Sci. 7 (2008) 543-552.

[11] G. Soreanu, M. Beland, P. Falletta, B. Ventresca, P. Seto, Evaluation of different packing media for anoxic $\mathrm{H}_{2} \mathrm{~S}$ control in biogas, Environ. Technol. 30 (2009) 1249-1259.
[12] A.B. Baspinar, M. Turker, A. Hocalar, I. Ozturk, Biogas desulphurization at technical scale by lithotrophic denitrification: integration of sulphide and nitrogen removal, Process Biochem. 46 (2011) 916-922.

[13] A.M. Montebello, M. Fernández, F. Almenglo, M. Ramírez, D. Cantero, M. Baeza, D. Gabriel, Simultaneous methylmercaptan and hydrogen sulfide removal in the desulfurization of biogas in aerobic and anoxic biotrickling filters, Chem. Eng. J. 200-202 (2012) 237-246.

[14] M. Fernández, M. Ramírez, R.M. Pérez, J.M. Gómez, D. Cantero, Hydrogen sulphide removal from biogas by an anoxic biotrickling filter packed with Pall rings, Chem. Eng. J. 225 (2013) 456-463.

[15] W.M. Haynes, Physcial constants of inorganic compounds, in: W.M. Haynes (Ed.), CRC Handbook of Chemistry and Physics, CRC Press/Taylor and Francis, Boca Raton, FL, 2012.

[16] M.C. Portillo, D. Villahermosa, A. Corzo, J.M. Gonzalez, Microbial community fingerprinting by differential display-denaturing gradient gel electrophoresis, Appl. Environ. Microbiol. 77 (2011) 351-354.

[17] J.M. Gomez, D. Cantero, C. Webb, Immobilisation of Thiobacillus ferrooxidans cells on nickel alloy fibre for ferrous sulfate oxidation, Appl. Microbiol. Biotechnol. 54 (2000) 335-340.

[18] L.S. Clesceri, A.E. Greenberg, A.D. Eaton (Eds.), Standard Methods for the Examination of Water and Wastewater, 20th ed., American Public Health Association, Washington, DC, 1999.

[19] R. Sierra-Alvarez, R. Beristain-Cardoso, M. Salazar, J. Gomez, E. Razo-Flores, J.A. Field, Chemolithotrophic denitrification with elemental sulfur for groundwater treatment, Water Res. 41 (2007) 1253-1262.

[20] D. Gabriel, M. Deshusses, Retrofitting existing chemical scrubbers to biotrickling filters for $\mathrm{H}_{2} \mathrm{~S}$ emission control, PNAS 100 (2003) 6308-6312.

[21] T. Sakuma, T. Hattori, M.A. Deshusses, Comparison of different packing materials for the biofiltration of air toxics, J. Air Waste Manage. Assoc. 56 (2006) 1567-1575.

[22] M. Fortuny, J. Baeza, X. Gamisans, C. Casas, J. Lafuente, M. Deshusses, D. Gabriel, Biological sweetening of energy gases mimics in biotrickling filters, Chemosphere 71 (2008) 10-17.

[23] B. Krishnakumar, V.B. Manilal, Bacterial oxidation of sulphide under denitrifying conditions, Biotechnol. Lett. 21 (1999) 437-440.

[24] M. Mohseni, Biological treatment of waste gases containing inorganic compounds, in: Z. Shareefdeen, A. Singh (Eds.), Biotechnology for Odor and Air Pollution Control, Springer, Berlin/Heidelberg, Germany, 2005, pp. 253-279.

[25] G. Claus, H. Kutzner, Autotrophic denitrification by Thiobacillus denitrificans in a packed bed reactor, App. Microbiol. Biotechnol. 22 (1985) 289-296.

[26] J.H. Park, H.S. Shin, I.S. Lee, J.H. Bae, Denitrification of high $\mathrm{NO}_{3}(-)$-N containing wastewater using elemental sulfur; nitrogen loading rate and $\mathrm{N}_{2} \mathrm{O}$ production, Environ. Technol. 23 (2002) 53-65.

[27] C. Chen, N. Ren, A. Wang, Z. Yu, D.J. Lee, Simultaneous biological removal of sulfur, nitrogen and carbon using EGSB reactor, Appl. Microbiol. Biotechnol. 78 (2008) 1057-1063.

[28] A.-J. Wang, D.-Z. Du, N.-Q. Ren, J. Van Groenestijn, An innovative process of simultaneous desulfurization and denitrification by Thiobacillus denitrificans, J. Environ. Sci. Health Part A Toxic/Hazard. Subst. Environ. Eng. 40 (2005) 1939-1949.

[29] I. Manconi, A. Carucci, P. Lens, S. Rossetti, Simultaneous biological removal of sulphide and nitrate by autotrophic denitrification in an activated sludge system, Water Sci. Technol. 53 (2006) 91-99.

[30] M.-F. Shao, T. Zhang, H.H.-P. Fang, Sulfur-driven autotrophic denitrification: diversity, biochemistry, and engineering applications, Appl. Microbiol. Biotechnol. 88 (2010) 1027-1042.

[31] J.K. Thomsen, T. Geest, R.P. Cox, Mass spectrometric studies of the effect of pH on the accumulation of intermediates in denitrification by Paracoccus denitrificans, Appl. Environ. Microbiol. 60 (1994) 536-541.

[32] E. Smet, P. Lens, H. Van Langenhove, Treatment of waste gases contaminated with odorous sulfur compounds, Crit. Rev. Env. Sci. Technol. 28 (1998) 89-117.

[33] A. González-Sánchez, S. Revah, M.A. Deshusses, Alkaline biofiltration of $\mathrm{H}_{2} \mathrm{~S}$ odors, Environ. Sci. Technol. 42 (2008) 7398-7404.

[34] A.J.H. Janssen, S.C. Ma, P. Lens, G. Lettinga, Performance of a sulfide-oxidizing expanded-bed reactor supplied with dissolved oxygen, Biotechnol. Bioeng. 53 (1997) 32-40.

[35] G. Soreanu, P. Falletta, P. Seto, Process optimization of $\mathrm{H}_{2} \mathrm{~S}$ removal from biogas in an anoxic biotrickling filter, in: Proceeding of IWA World Water Congress and Exhibition, IWA publishing, Montreal, 2010, pp. paper\#IWA-2653.

[36] M. Tomàs, M. Fortuny, C. Lao, D. Gabriel, F. Lafuente, X. Gamisans, Technical and economical study of a full-scale biotrickling filter for $\mathrm{H}_{2} \mathrm{~S}$ removal from biogas, Water Pract. Technol. 4 (2009), http://dx.doi.org/10.2166/wpt.2009.026.

[37] M. Miltner, A. Makaruk, J. Krischan, M. Harasek, Chemical-oxidative scrubbing for the removal of hydrogen sulphide from raw biogas: potentials and economics, Water Sci. Technol. 66 (2012) 1354-1360. 